\title{
Kratom, Legal or Illegal Drug?
}

\author{
Diaz Ruiz S* and Ramos Campoy E \\ Forensic Physician, Institute of Legal Medicine of Málaga, Spain
}

Submission: July 13, 2017; Published: August 01, 2017

*Corresponding author: Sebastián Díaz, Instituto de Medicina Legal, Málaga Urb. El Lagarejo, 168. Mijas 29651. Málaga, Spain, Email: chanivito@gmail.com

Abstract

The concept of emerging drugs has replaced the concepts of designer drugs or recreational drugs, by the continuous creation of new psychoactive substances. Within the emerging drug substances are included others considered "legal highs". This concept is used to refer to those substances not included in the list of prohibited drugs and they are sold as "legal" in smart shops, grow shops or online stores on the internet. One of these substances that may be included within this latter concept of "legal highs" would be the kratom. These are plants with psycho active effects but sold legally in many countries worldwide. In this review we wondered whether to proceed with illegalisation.

Keywords: Kratom; Legal highs; Emerging drugs; Forensic toxicology

\section{Review}

The concept of emerging drugs has replaced, by consensus, to the concepts of designer drugs, synthetic drugs or recreational drugs. The fact start calling these substances as drugs is emerging because of the new creation of a toxic substance but by the new appearance as a substance already known, or used for other purposes or are often recurrences of previously known and used substances. These substances most often are not included in the lists of drugs or illegal substances. Generally are also known as "legal highs" or "smart drugs", as they are produced by mixing various herbs or synthetic substances laboratory, but that not being included in the lists of illegal substances are considered "legal". With this appearance of legality are sold at stores open to the public in different cities, but above all, and where they are expanding so uncontrolled these substances are the sales that take place in the online stores, known as "smarts shops".

According to the annual report of the European Monitoring Centre for Drugs and Drug Addiction (EMCDDA) of 2010 [1], there were 170 virtual network shops that traded these substances. Most of them labelled as herbs or mixtures of herbs and giving the appearance that are not harmful to the body. But that is not controlled by health registration substances, causes are not known in many cases the content of these substances and this means that it cannot determine its harmful health effects. These substances are often associated with raves or after parties or clubbers or dance clubs, why they are sometimes called as "club drugs". It is clear that as the world has globalized, sale of narcotics has also tended to this globalization, so it must be fought by other means.

One of these substances is the Kratom, but is it really such substances legal or opened to include it in the list of psychotropic substances banned? In the last year we've heard of this substance in various internet forums, where would refer to it as the ideal case for opioid detoxification substitute. This substance is extracted from the plant Mitragyna speciosa [2], of which several alkaloids that have been used in traditional medicine as analgesics in musculoskeletal, antitussive, antidiarrheal and antihypertensive obtained. This plant is native to eastern Asia and Oceania, which is referred to it as "Kratom" in Thailand and "Biak-Biak" in Malaysia [3]. This plant has been used by workers in these areas of the world as a stimulant to fatigue of work in low doses. In her more than 20 alkaloids, many with active properties where mitragynine, is the busiest and extracted in larger quantities are extracted. The activity of alkaloids extracted based on different types of plants, if more or less new plant. The more active substances are mitragyne and 7-hydroxy-mitragyne, the latter being 10 times more potent than morphine.

Traditionally in the origin countries they take the fresh or dried leaves of kratom chewed or brewed into tea. When making tea, lemon juice is often added to facilitate the extraction of plant alkaloids; before drinking, sugar or honey may be added to mask the bitter taste of the brew. The dried leaves are occasionally smoked. Normally they chew one to three 
fresh leaves at a time. The veins are usually removed from the leaves before eating. Regular and addicted users chew 3 to 10 times a day [3]. Described that these substances have similar biological activity classical opiates, which are extracted from the opium poppy (Papaver somniferum), as presented in the $\mu$ receptor activity, has competitive receptor activity and pathways naloxone analgesia have used cross-tolerance to morphine. This substance used chronically and at high doses, will have an equal activity to other opiates, withdrawal and dependence. Often these symptoms are more pronounced and longer lasting than those caused by morphine itself. Also be causing tolerance, so you need to consume kratom more frequently and at higher doses to achieve the same effects [4].

After taking a few grams of dried leaves, the invigorating effects and euphoria are felt within 10 minutes and last for one to one and a half hours. Kratom users report increased work capacity, alertness, and sociability and sometimes heightened sexual desire. The pupils are usually normal or very slightly contracted; blushing may be noted. For regular kratom users, loss of weight, tiredness, constipation, and hyper pigmentation of the cheek may be notable side effects. The pharmacological mechanism responsible for stimulant activity is unclear. Kratom taken in large, sedating doses corresponding to $10-25 \mathrm{~g}$ of dried leaves may initially produce sweating, dizziness, nausea and dysphoria but these effects are shortly superseded with calmness, euphoria and a dreamlike state that last for up to six hours. Contracted pupils are noted [4].

For all that this substance was considered as an illegal drug in 4 countries(Australia, Malaysia, Thailand and Myanmar), though this substance has spread to Europe and the United States, where it is still legal, and even can be bought freely on the Internet, This page that you link explains among other things which are the beneficial effects of kratom, what dose to take, where to buy legally, as well as offering a wide variety of kratom as the extraction method followed and characteristics of the different plants, with a list of them and the prices of each. They can also be purchased at different forms as whole leaf, like chopping plants extracts in capsules, in the form of tea bags.

In many of these sites where consumer blogs describing their own experiences with these substances, in most cases pleasant situations described and always emphasizing the differences from the classical opiates but other pages consumers include described the first cases of withdrawal and dependence. Prices of the substance vary between countries and depend on the type and amount of the product purchased. According to the
EMCDDA Internet surveys conducted in 2008 [2], the prices of 'Kratom 15X' extracts ranged from EUR 2.1 to 10.3 per gram in the sampled European countries. In 2011, a follow-up EMCDDA snapshot of 314 online shops found that prices ranged from EUR 6 to 15 per 10 gram of dried kratom and EUR 7 to 8 per gram of 'Kratom 15X' extract.

Recently, in 2013, the United Nations Office on Drugs and Organized Crime United Nations [5], noted as a substance that should be included in the list of psychotropic substances prohibited. Its use worldwide is increasing, surpassing the borders of the countries of East Asia where it originated. According to the European Monitoring Centre for Drugs and Drug Addiction (EMCDDA) any of the mitragynine speciosa alkaloid of this plant is included in any of the Schedules of the drug conventions of the United Nations. In September 2011 it has been considered as a substance that is brought under control in some countries of the European Union such as Denmark, Latvia, Lithuania, Poland, Romania and Sweden. In the US, kratom is not controlled, although considered a "drug of concern." Therefore, in the present, except for the 4 countries in which this substance is banned, we can consider the kratom as a "legal high" and thus counter.

\section{Conclusion}

Kratom is an alkaloid substance obtained from the Mitragyna speciosa plant, traditionally consumed in East Asiaasinvigorating and against fatigue. However it has been introduced in the market of substances of abuse such as "legal high", as alegal substitute substance of euphoric products (cocaine, amphetamine). Due to the toxic effects caused, in Europe should be included in the lists of prohibited psychotropic drugs, following the example of countries such as Australia, Malaysia, Thailand and Myanmar. Now EMCDDA put under vigilance this substance waiting to include it in the prohibited substances.

\section{References}

1. Drugs National Report 2010: Spain EMCDDA, Lisbon, Portugal.

2. EMCDDA (2006) Drugs profile. Kratom (Mytragyna speciosa).

3. Adkins JE, Boyer EW, McCurdy CR (2011) Mitragyna speciosa, a psychoactive tree from Southeast Asia with opioid activity, Current Topics in Medicinal Chemistry 11(9): 1165-1175.

4. Houghton P, Shellard E (2006) Kratom chemistry. New Scientist 192: 25.

5. United Nations Office on Drugs and Crime. New psychoactive substances (NPS). World Durg Campaign, vienna, Austria. 
This work is licensed under Creative Commons Attribution 4.0 License

DOI: $10.19080 /$ JFSCI.2017.04.555633

\section{Your next submission with Juniper Publishers} will reach you the below assets

- Quality Editorial service

- Swift Peer Review

- Reprints availability

- E-prints Service

- Manuscript Podcast for convenient understanding

- Global attainment for your research

- Manuscript accessibility in different formats

( Pdf, E-pub, Full Text, Audio)

- Unceasing customer service

Track the below URL for one-step submission

https://juniperpublishers.com/online-submission.php 